\title{
Erzya Language
}

National Cancer Institute

\section{Source}

National Cancer Institute. Erzya Language. NCI Thesaurus. Code C154042.

A Uralic language spoken in the northern, eastern, and north-western parts of the Republic of Mordovia and adjacent regions of Nizhny Novgorod, Chuvashia, Penza, Samara, Saratov, Orenburg, Ulyanovsk, Tatarstan, and Bashkortostan in Russia. 